\title{
PENINGKATAN KUALITAS ARSIPARIS \\ MELALUI PERSONAL BRANDING
}

\author{
Ully Isneni Effendi ${ }^{l}$
}

\begin{abstract}
Abstrak
Sumber daya manusia (SDM) sebagai penggerak organisasi dituntut untuk mempunyai kualitas yang baik. Perkembangan zaman yang terus berubah menuntut SDM untuk terus berubah, karena peningkatan kualitas SDM menjadi salah satu syarat yang utama, dan hal tersebut berlaku juga bagi arsiparis. Salah satu cara peningkatan kualitas SDMadalah dengan personal branding. Arsiparis dituntut untuk mempunyai personal branding yang lebih baik lagi agar dapat bersaing di pasaran (SDM).
\end{abstract}

Kata kunci: personal branding, sumber daya manusia (SDM), arsiparis

\section{PENDAHULUAN}

\section{A. Latar Belakang}

Tidak banyak sumber daya manusia (SDM) yang mengetahui "nilai" (value) akan dirinya sendiri yang dapat "dijual" kepada "pasar" SDM. Potensi SDM bisa jadi kurang diketahui atau bahkan kurang disadari. Melihat kondisi saat ini, SDM dituntut untuk 'ready to work'" atau lebih tepatnya adalah SDM mampu mempersiapkan diri kedalam persaingan pasar tenaga kerja yang semakin lama semakin menuntut SDM untuk lebih banyak mengeksplor kemampuannya.

Dalam ilmu ekonomi dikenal dengan istilah supply dan demand, sama halnya dengan "pasar" SDM tersebut, ada supply dan demand juga. Di "pasar" tersebut akan ada namanya transaksi supply dan demand yang akan berakhir dengan keputusan "buying” atau "membeli" atau bahkan 
keputusan "cancel" atau “membatalkan" rencana pembelian. Tanpa kita sadari, sebenarnya SDM-pun juga masuk ke dalam aktifitas "market" dan "marketing". SDM yang berkualitas tinggi akan berbeda dengan SDM yang berkualitas rendah, baik dari segi nilai (value) maupun harga jualnya. Semuanya tergantung pada apa yang ada dalam diri SDM tersebut. Paket apa yang ada pada SDM tersebut, apakah paket lengkap ataukah paket hemat.

Organisasi yang dinamis, terus berubah seiring dengan perkembangan zaman, akan membutuhkan SDM yang siap berubah, mau berubah, dan terus berubah. Segala sesuatu pasti mengalami perubahan, karena yang statis hanyalah perubahan itu sendiri. Proyeksi ke depan, permintaan pasar terhadap kualitas SDM akan semakin meningkat, karena SDM merupakan salah satu roda bergeraknya suatu organisasi. SDM tidak hanya sebagai SDM, tetapi SDM juga sebagai aset suatu organisasi.

\section{B. Rumusan Masalah}

Permasalahannya sekarang adalah bagaimana membangun personal branding untuk meningkatkan kualitas arsiparis sebagai upaya memenuhi permintaan pasar dan mengikuti perkembangan zaman?

\section{Kerangka Pemikiran}

Pengertian SDM menurut Malayu Hasibuan (2005) adalah kemampuan terpadu dari daya pikir dan daya fisik yang dimiliki oleh suatu individu. Daya pikir tersebut diperoleh dari kecerdasan sejak lahir atau bawaan lahir, dimana hal tersebut merupakan modal dasar penentuan kualitas SDM, meskipun ada faktor-faktor lain ( e k s t e r n a l) y a $\mathrm{n} \mathrm{g}$ mempengaruhinya. Pelaku dan sifatnya dipengaruhi oleh lingkungan dan keturunannya, sedangkan prestasi kerja dimotivasi oleh keinginan agar bisa memenuhi kepuasan. SDM 
menjadi unsur utama dan memegang peranan penting dalam setiap kegiatan yang dilakukan dalam suatu organisasi. SDM menjadi penggerak untuk dapat mencapai tujuan organisasi itu sendiri. Kualitas dan kecakapan SDM menjadi penting mengingat peranannya tersebut.

Konsep personal branding merupakan sebuah proses dalam diri (individu) untuk menghasilkan nilai (keahlian, sikap, kompetensi, dsb) yang menimbulkan ketertarikan individu lain dalam hal-hal tertentu yang dapat dimanfaatkan di kemudian hari. Personal branding dapat berupa keahlian fisik yaitu eksistensi melalui bidang yang ditekuni (untuk arsiparis berarti bidang kelimuan kearsipan) dan spiritual yaitu menunjukkan eksistensi diri karena faktor sikap, kepribadian, maupun halhal yang tidak dapat diukur dengan angka.

Terdapat banyak konsep atau pandangan mengenai personal branding, salah satunya adalah menurut Rein and a 1 ( 20006$)$ y a ng mendefinisikan personal branding sebagai sebuah pendekatan individualistik. Ditambahkan oleh Peters (1997) yang mengatakan bahwa premis utama untuk personal branding adalah bahwa setiap orang dapat dianggap sebagai merek, setiap orang memiliki merek pribadi dan tanpa memandang usia, terlepas dari posisi, terlepas dari bisnis. Setiap orang memiliki kesempatan untuk menjadi merek dan apabila personal branding diterapkan dengan benar dapat mengubah setiap orang menjadi merek dalam bidang apapun.

Lain halnya dengan Montoya (2002), McNally and Speak (2002), Arruda and Dixson, (2007) yang sama-sama mengidentifikasikan personal branding sebagai sebuah konsep pemasaran baru yang terkait dengan strategi pemasaran dimana seseorang mengadopsi d a lam rangka untuk 
mempromosikan dirinya di pasar.

Menurut Ramparsad (2009) kebanyakan orang tidak menyadari bahwa setiap orang memiliki merek pribadi dan tidak mengelolanya strategis, konsisten, dan efektif. Sebuah proposisi penjualan utama adalah ketakutan bahwa jika individu tidak mengelola merek mereka sendiri, maka orang lain akan mengelola untuk mereka: "Jika Anda tidak memereki sendiri, orang lain akan", tulis Kaputa (2003), yang meneruskan: "Anda memberikan kekuatan kepada orang lain untuk merek Anda jika Anda tidak melakukannya sendiri"

Dari berbagai pendapat tentang personal branding, dapat dikatakan bahwa personal branding merupakan segala sesuatu yang berhubungan dengan seseorang atau dapat dikatakan sebagai merek pribadi. Personal branding dapat dilakukan dengan banyak cara. Menurut Hermawan Kertajaya dalam Marketing Yourself
(2005), yang perlu diingat adalah kemauan yang kuat dalam diri untuk melakukan personal branding. Menjadi diri sendiri, tunjukkan kelebihan diri, lakukan inovasi, bertanggung jawab dengan apa yang diri lakukan, membuat arah tujuan serta capaian diri, dan yang tidak kalah penting adalah buka wawasan. Sebenarnya personal branding dapat diawali dari diri sendiri, yaitu nama karena akan melekat dalam diri. Oleh karena itu, untuk membangun personal branding harus memperhatikan hal-hal sebagai berikut:

1. Jangan menganggap nama hanya sekedar nama

Nama harus diketahui oleh banyak orang dan orang lain harus mengerti asosiasi yang melekat pada nama tersebut

\section{Buildyour own brand}

Setiap orang mempunyai kewajiban untuk membangun brand (merek) sendiri, walaupun pada awalnya hanya sedikit orang yang mengetahui tetapi lamakelamaan semakin banyak 
orang yang akan mengenal.

3. Menjaga nama baik

Nama mencerminkan diri kita, maka jangan sampai nama kita rusak, because brand is value.

Nama dan yang melekat dalam nama tersebut akan berpengaruh terhadap diri, berpengaruh terhadap nilai jual diri, dan nilai institusinya. Nama baik dan terkenal akan meningkatkan nilai diri beserta institusinya.

Selain itu, Prof. DR. Din Syamsudin menyebutkan bahwa personal branding merupakan hal yang sangat alamiah karena m a n s i a me miliki kecenderungan untuk menonjolkan dirinya (www.kompasiana.com). Personal branding dapat terbentuk melalui sikap seharihari serta kesan orang lain, bahkan mengganti nama pun juga merupakan usaha untuk membangun personal branding. Dalam kehidupan sehari-hari pastilah melakukan kegiatankegiatan yang terus dilakukan yang akhirnya memunculkan suatu kebiasaan. Kebiasaankebiasaan tersebut akan memunculkan karakter yang nantinya akan menjadi salah satu penilaian orang lain. Bahkan cara berpenampilan atau berpakaian juga dapat mencerminkan diri. Seseorang dengan penampilan kerja yang bersih, rapi, sopan, fashionable, wangi akan membuat image seseorang tersebut baik. Berbeda dengan seseorang yang berpenampilan kerja seadanya, tidak rapi, kumal, atau bahkan tidak sopan akan membuat image seseorang tersebut menjadi tidak baik.

Personal branding dapat dikatakan sebagai citra diri atau yang dapat menggambarkan diri seseorang (SDM). Citra diri tersebut mempunyai kekhasan atau citra tersendiri. Sebagai contoh adalah dr. Ryan Thamrin. Masyarakat umum mengenal Ryan Thamrin sebagai dokter muda pembawa acara Dr. OZ Indonesia di Trans TV, namun selain itu orang mengingat dr. Ryan Thamrin adalah seorang 
yang muda, pintar, tampan, selalu fresh, mantan model cover boy, good looking, dsb. Hal yang telah disebutkan itu merupakan citra diri seorang dr. Ryan Thamrin. Orang lain menilai dari melihat apa yang ditampilkan dari diri dr. Ryan Thamrin dalam acara tersebut. Citra diri tersebut tidak secara langsung atau tidak secara instan muncul. Orang harus melihat secara berulang-ulang. Sama halnya dengan produk, sebagai contoh adalah iPhone, orang mengingat $i$ Phone sebagai smartphone (handphone yang smart) yang canggih, desain elegan, fiturnya lengkap, harganya mahal, serta masuk di kelas premium. Dari mana itu muncul? Hal tersebut muncul dari yang ditampilkan secara fisik dari produk iPhone tersebut.

Itulah personal branding, mencitrakan diri sesuai dengan kapasitas serta kualitas yang dimilikinya. Brand menjadi penting ketika masyarakat melihat pada saat pertama kali atau pada saat perkenalan. Masyarakat akan berusaha mencari tahu brand sebelum memberikan pilihannya terhadap brand tersebut. Masyarakat membutuhkan penguatan atau keyakinan akan brand. Dengan posisi brand yang kuat dan positif menyebabkan masyarakat menjadi percaya (trust) akan brand tersebut. Brand akan berbicara sendiri. Oleh karena itu, brand itu menjadi penting, sama halnya dengan personal branding.

\section{PEMBAHASAN}

\section{A. SDM Kearsipan: Arsiparis}

Pengertian arsiparis menurut Keputusan Menteri Pendayagunaan Aparatur Negara dan Reformasi Birokrasi RI Nomor 48 Tahun 2014 tentang Jabatan Fungsional Arsiparis adalah seorang pegawai negeri sipil yang memiliki kompetensi di bidang kearsipan yang diperoleh melalui pendidikan formal dan/atau pendidikan dan pelatihan kearsipan serta mempunyai fungsi, tugas, dan tanggung jawab melaksanakan 
kegiatan kearsipan yang diangkat oleh pejabat yang berwenang di lingkungan lembaga negara, pemerintahan daerah, pemerintahan desa dan satuan organisasi perguruan tinggi negeri. Seorang arsiparis mempunyai tugas yang berhubungan dengan kegiatan kearsipan yaitu kegiatan yang berkesinambungan dalam pengelolaan arsip secara manual dan/atau elektronik, dimulai dari proses penciptaan, penggunaan dan pemeliharaan, penyusutan, akuisisi, preservasi dan pelestarian, publikasi, pelayanan, pembinaan, bimbingan dan supervisi, serta akreditasi dan sertifikasi kearsipan.

Terdapat kegiatan kearsipan yang sifatnya dikerjakan secara individu maupun tim, dan kegiatan yang berhubungan dengan orang lain diluar institusinya. Hal ini secara tidak langsung membutuhkan kemampuan berkomunikasi dan berinteraksi dengan orang lain. Kemampuan berkomunikasi dan berinteraksi dengan orang lain juga sangat erat kaitannya dengan diri arsiparis tersebut, karena tiap arsiparis mempunyai karakter yang berbeda. Sebagai contoh ada arsiparis yang merupakan paket lengkap karena mempunyai kemampuan keilmuan kearsipan yang bagus ditambah dengan kemampuan berkomunikasi yang baik, penampilan menarik, dan body language-nya bagus. Tidak semua arsiparis mempunyai kemampuan seperti itu, tetapi tidak menutup kemungkinan arsiparis untuk meningkatkan kemampuannya dengan jalan mempelajarinya. Kegiatan kearsipan tersebut sangatlah lengkap, karena semuanya membutuhkan kombinasi antara ilmu dan ketrampilan teknis. Melihat tugas seorang arsiparis tersebut, dapat dikatakan bahwa seorang arsiparis dituntut untuk mampu dan menguasai banyak hal. Dibutuhkan tidak hanya segi keilmuan bidang kearsipan tetapi juga dibutuhkan kecakapan, kemampuan, 
ketrampilan, dan keahlian lainnya yang mampu mendukung tugasnya.

\section{B. Personal Branding Arsiparis}

Masih banyak orang atau institusi yang menganggap arsiparis sebagai pekerjaan yang tidak populer, bahkan ada yang menganggap pekerjaan yang tidak bergengsi, kurang mendapat apresiasi, serta profesi yang dienggani (bukan disegani). Mengapa orang berpandangan seperti itu? Banyak alasan orang melihat profesi arsiparis seperti itu, salah satunya adalah dari diri SDM (arsiparis) itu sendiri. Tanpa disadari diri atau pribadi arsiparis turut berkontribusi dalam penyematan pekerjaan tidak populer, tidak bergengsi, dan "hanya menata arsip" pada diri mereka. Salah satu penyebabnya adalah kurang atau tidak adanya usaha meningkatkan kualitas atau nilai (value) diri arsiparis. Saat ini sudah tidak zamannya arsiparis "hanya" bekerja "menata arsip". Arsiparis mampu berkembang menjadi "lebih" dari itu.

Personal branding juga berlaku bagi profesi arsiparis. Arsiparis juga perlu memiliki personal branding sebagai usaha agar orang percaya (trust) akan profesi tersebut. Selain itu agar brand arsiparis menjadi lebih dibandingkan dengan brand arsiparis yang sudah ada. Langkah awal dalam membangun personal branding adalah mulailah mengenali diri sendiri, yaitu mengenali diri sendiri mengenai hal yang disukai, keahlian, passion, potensi, kelebihan dan kekurangan, dll. Langkah selanjtnya mulailah membangun dan menunjukkan personal branding dengan cara sebagai berikut:

1. berpikir positif

Berpikir positif berarti mencoba melihat, memandang serta menyikapi segala sesuatu secara positif dari sudut pandang yang lebih baik. Berpikir positif 
akan membuat hal yang sulit menjadi lebih mudah dan mungkin untuk dilakukan.

2. memiliki dan membangun sikap yang simpatik dan baik

3. mengikuti kegiatanyang berhubungan dengan bidang kerja

Kegiatan yang diikuti adalah yang ada kaitannya dengan bidang kerja seorang arsiparis, baik itu secara internal maupun ekternal.

4. meningkatkan motivasi secara terus menerus dengan bergabung dengan kelompok atau komunitas yang sesuai dengan bidang kerja

Bergabung dengan kelompok atau komunitas sesama arsiparis akan meningkatkan motivasi. Arsiparis dapat menjadi anggota forum arsiparis baik skala lokal maupun nasional seperti Forum Kearsipan Universitas Gadjah Mada (FORSIPAGAMA), Forum Masyarakat Kearsipan
(FMK), Asosiasi Arsiparis Indonesia (AAI), dsb.

5. sharing ilmu, inovasi dan ide baru kepada orang lain Berbagi dapat dilakukan dengan saling bertukar pe n g a la man a t a u pengetahuan kepada orang lain, baik yang berkaitan dengan bidang kearsipan ataupun tentang bidang lainnya. Berbagi akan membuat kita akan kaya, kaya ilmu, wawasan, manfaat, dll.

6. berkarya

Seperti ungkapan filsuf Rene Descartes yaitu "cogito ergo sum" yang artinya adalah aku berpikir maka aku ada. Ungkapan tersebut dimaknai bahwa manusia yang berpikir adalah manusia yang diakui keberadaannya atau eksis akan lebih lengkap dengan berkarya. Berkarya merupakan aktivitas yang menghasilkan sesuatu yang bisa dirasakan dan diapresiasi oleh orang lain. 
Salah satu contoh berkarya bagi seorang arsiparis adalah dengan cara menulis tentang kearsipan maupun topik lainnya sesuai dengan keahliannya.

7. berprestasi

Prestasi merupakan hal yang diperoleh dari upaya yang telah dilakukan, dengan mengandalkan kemampuan intelektualnya. Prestasi dapat berupa penghargaan, promosi, dll.

Setiap SDM pada dasarnya memiliki kekuatan atau kelebihan masing-masing, dimana kekuatan atau kelebihan tersebut dapat diolah dan dikembangkan menjadi potensi. Kekuatan atau kelebihan tersebut tidak selalu harus berkaitan langsung dengan bidang ilmu kearsipan atau profesi arsiparis. Kekuatan atau kelebihan tersebut dapat berupa keahlian masing-masing SDM. Permasalahannya adalah apakah arsiparis tersebut mengenali keahlian masing-masing? Arsiparis harus mulai mengenali diri sendiri, hal ini berguna dalam menganalisa apa yang disukai, keahlian, passion, potensi, kelebihan dan kekurangan dirinya. Apabila telah teranalisa maka dapat diambil langkah selanjutnya atau rencana untuk maju atau berkembang dengan tujuh langkah tersebut.

Usaha membangun personal branding lainnya adalah bahwa pada era teknologi informasi yang semakin canggih ini, memungkinkan arsiparis untuk berkomunikasi dengan dunia luar selain dengan internal institusinya. Media sosial seperti blog, website, youtube, facebook, twitter, instagram, path, dsb. dapat digunakan sebagai media untuk membangun personal branding. Media sosial tersebut dapat digunakan sebagai tempat untuk menuangkan ide, inovasi, gagasan, penemuan atau bahkan penelitian terkait dengan bidang ilmu kearsipan atau terkait profesi arsiparis kepada dunia luar. Media sosial dapat 
d i g u n a k a n u n t u k memperkenalkan diri SDM (arsiparis) melalui kegiatankegiatan diri yang berkaitan dengan bidang ilmu kearsipan dan profesi arsiparis sehingga dunia luar dapat mengetahui kegiatan apa saja yang dapat dilakukan oleh seorang arsiparis. Caranya adalah dengan mengunggah kegiatankegiatan ke dalam media sosial. Memperluas jaringan dengan sesama rekan seprofesi tetapi lain institusi, atau dengan profesi yang berlainan, serta orangorang baru yang bahkan tidak ada hubungannya dengan profesi arsiparis sebagai sarana untuk bertukar pikiran. Arsiparis juga dapat meningkatkan kualitasnya dengan cara menambah wawasan atau pengetahuan yang tidak berhubungan langsung dengan bidang ilmunya tetapi dapat mendukung dirinya sebagai seorang arsiparis. Semakin arsiparis dikenal, maka personal branding akan semakin kuat, dan tentunya akan semakin diingat. Hal yang perlu diingat adalah harus dilakukan secara konsisten dan berkelanjutan, karena personal branding merupakan sebuah proses yang dilakukan terus menerus.

Selain melalui media sosial, cara lain yang dapat dilakukan arsiparis sebagai usaha peningkatan personal branding arsiparis salah satunya adalah meningkatkan kualitas diri dengan mengikuti pendidikan dan pelatihan yang sesuai dengan kualifikasi arsiparis, spesialisasi (keilmuan), serta bidang tugas arsiparis. Sebagaimana yang tercantum dalam Undang-Undang No.43 Tahun 2009 tentang Kearsipan, pasal 30 yaitu pengembangan SDM yang memiliki kompetensi dan profesionalitas di bidang kearsipan. Pendidikan dan pelatihan tersebut sangat beragam, sebagai contoh adalah pendidikan dan pelatihan (diklat) teknis yang diadakan oleh Arsip Nasional Republik Indonesia (ANRI) seperti:

1. pengelolaan arsip dinamis 
2. dasar-dasar kearsipan

3. program arsip vital

4. training of trainers (TOT) kearsipan

5. penyusutan arsip

6. akuisisi

7. alih media arsip

8. dll.

Diklat tersebut akan semakin memperkaya keilmuan serta kualitas diri arsiparis, karena diklat tersebut bertujuan untuk meningkatkan pengetahuan, keahlian, kecakapan, dan ketrampilan arsiparis. Cara lainnya adalah dengan mengikuti pelatihanpelatihan yang mendukung bidang kerjanya, seperti pelatihan bahasa asing yang berguna dalam pengolahan arsip, mengingat banyak terdapat arsip-arsip yang menggunakan bahasa asing. Ditambahkan pula bahwa selain pendidikan dan pelatihan tersebut, peningkatan kualitas SDM dengan jalan sertifikasi kompetensi jabatan arsiparis yang diselenggarakan oleh ANRI, agar arsiparis mampu menyelenggarakan kegiatan kearsipan dengan efektif dan efisien.

\section{Personal branding} penting dimiliki oleh arsiparis saat ini, di tengah era persaingan yang sangat ketat. Institusi tidak hanya membutuhkan arsiparis yang hanya memiliki kemampuan teoritis dalam bidang kearsipan namun juga membutuhkan arsiparis yang mampu beradaptasi dengan perubahan yang ada . Membangun personal branding akan memberikan banyak manfaat bagi arsiparis itu sendiri, sebagai contoh adalah masyarakat atau orang lain akan cenderung lebih mudah mengenali arsiparis, bahkan nilai tambahnya adalah menghormati. Ditambah lagi dengan prestasi serta pencapaian akan suatu keberhasilan, akan semakin menambah nilai arsiparis, yang menghasilkan kepercayaan (trust) yang kemudian akan meningkatkan nilai (value). Kualitas arsiparis tidak hanya 
ditentukan oleh ketrampilan saja tetapi juga ditentukan oleh pendidikan (pengetahuan), pengalaman serta kematangan dan sikap serta nilai-nilai yang dimilikinya. Arsiparis akan mempunyai karakter atau ciri khas yang unik, mampu bersaing, serta mempunyai daya jual yang tinggi. Tidak dapat dipungkiri bahwa keberhasilan dan kinerja seseorang dalam suatu bidang pekerjaan banyak ditentukan oleh tingkat kompetensi, profesionalisme dan juga komitmennya terhadap bidang pekerjaan yang ditekuninya.

\section{PENUTUP}

\section{A. Kesimpulan}

Berdasarkan pemaparan tersebut, personal branding dapat diartikan sebagai sebuah proses dalam diri SDM atau individu untuk menghasilkan nilai (value) dirinya dengan berbagai usaha dan cara agar dapat menghasilkan nilai (value) yang diharapkan. Nilai (value) tersebut dapat berupa kompetensi, keahlian, sikap, dll. Nilai (value) tersebut dapat menimbulkan ketertarikan bagi individu lain dalam halhal tertentu untuk dapat bermanfaat dikemudian hari, sebagai contoh adalah seperti institusi yang tertarik untuk mempekerjakan SDM dengan nilai (value) tersebut.

Bagi SDM kearsipan, dalam hal ini adalah arsiparis, setiap arsiparis memiliki kelebihan dan kekurangan masing-masing. Kelebihan berupa kekuatan, baik yang terkait dengan kompetensi dan keahlian bidang kearsipan maupun bidang lain yang mendukung "personal branding”-nya. Ditengah era persaingan yang sangat ketat saat ini, personal branding penting untuk dimiliki setiap arsiparis. Institusi yang maju tidak hanya membutuhkan SDM yang memiliki kemampuan akademis saja, tetapi juga kemampuan lainnya seperti kemampuan beradaptasi menyesuaikan 
dengan perubahan lingkungan yang cepat serta kemampuan untuk menghadapi dan menyelesaikan masalah.

\section{B.Saran}

Tidak mudah membangun personal branding tetapi juga tidak sulit untuk memulai untuk berubah ke arah yang lebih baik lagi. Setiap arsiparis dapat membentuk personal branding-nya sendiri. Mengingat profesi arsiparis yang dibutuhkan di berbagai institusi dan persaingan SDM yang semakin ketat, mau tidak mau menuntut arsiparis untuk lebih maju dan berwawasan luas agar tidak tergeser dan tenggelam. Oleh karena itu, arsiparis dituntut untuk berubah, salah satunya dengan personal branding sebagai usaha penguatan akan dirinya sendiri. Tidak boleh dilupakan bahwa setiap arsiparis memiliki personal branding sendiri-sendiri, hanya saja seberapa kuat personal branding itu mampu terekam dengan kuat di benak orang lain itu yang berbeda-beda. Selain itu perlu diperhatikan juga bahwa akan ada dampak yang dihasilkan dari personal branding yaitu dampak negatif atau positif yang akan berpengaruh terhadap diri arsiparis itu sendiri. Tinggal bagaimana arsiparis tersebut memilih, apakah positif atau negatif. Mulaila h meningkatkan kualitas diri sebagai langkah penguatan diri agar dapat bersaing dengan SDM lainnya. Let's improveyour qualities!! 


\section{DAFTAR PUSTAKA}

Undang-Undang RI No.43 Tahun 2009 tentang Kearsipan

Keputusan Menteri Pendayagunaan Aparatur Negara dan Reformasi Birokrasi RI Nomor 48 Tahun 2014 tentang Jabatan Fungsional Arsiparis.

Arruda, W. \& Dixson, K. 2007. Career Distinction, Stand Out by Building Your Brand, New Jersey: JohnWiley \& Sons, Inc., Hoboken.

Hasibuan, Malayu SP. 2005. Manajemen: Dasar, Pengertian, dan Masalah. Jakarta: Bumi Aksara.

Kertajaya, Hermawan. 2005. Marketing Yourself: Kiat Sukses Meniti Karir dan Bisnis. Jakarta: MarkPlus \& Co. PT Ikrar Mandiri Abadi.
Khedher, Manel, "Personal Branding Phenomenon". International Journal of Information Business and Management, Vol. 6, No. 2, 2014.

McNally, D. \& Speak, K.D. 2002. Be your own brand $-a$ breakthrough formula for standing out from the crowd, San Fransisco: BerrettKoehler.

Peters, T. 1997. The Brand Called You. Fast Company, 10, 8390.

Rein, I., Kotler, P., Hamlin, M., \& Stoller, M. (2005). High Visibility: Transforming Your Personal and Professional Brand. McGraw-Hill.

http://www.kompasiana.com/sam_m e/membangun-personābranding-yang-mempesonab u $\mathrm{k}$ a $\mathrm{n}$ manipulatif_54f7b4d5a3331 1641 e 8 b $4 \overline{8} 00$. Diakses tanggal 21 Maret 2016. 